\title{
Editorial
}

\section{Environmental Toxicants in Forensic Entomology}

\author{
Bashir M. Rezk, PhD ${ }^{1,2^{*}}$; Myles S. Masters, BS Student'; Geoffroy E. Sanga Pema, BS Student ${ }^{1,2}$; Wayne J.G. Hellstrom, MD, FACS ; \\ Asim B.Abdel-Mageed, DVM, PhD²; Suresh C. Sikka, PhD, HCLD ${ }^{2}$
}

'Department of Natural Sciences, Southern University at New Orleans, New Orleans, LA 70126, USA

${ }^{2}$ Department of Urology, Tulane University School of Medicine, New Orleans, LA 70I I 2, USA

\section{"Corresponding author}

Bashir M. Rezk, PhD

Associate Professor, Department of Natural Sciences, Southern University at New Orleans, 6400 Press Drive, New Orleans, LA 70126, USA;

Tel.+I(504)284-5405; E-mail: batteia@suno.edu

\section{Article information}

Received: December 18 ${ }^{\text {th }}$ 2018; Accepted: December 19 $9^{\text {th }}$ 2018; Published: December 21 ${ }^{\text {st }}, 2018$

\section{Cite this article}

Rezk BM, Masters MS, Pema GES, Hellstrom WJG, Abdel-Mageed AB, Sikka SC. Environmental toxicants in forensic entomology. Toxicol Forensic Med Open J. 2018; 3(I): el-e2. doi: 10.17I40/TFMOJ-3-e008

$\mathrm{T}$ The fundament of toxicology is the risk-benefit analysis. Certain chemical exists in the environment that if ingested, even in minute quantities, may alter bodily functions, induce death and interfere with the rate of decomposition of dead bodies. Ancient cultures discovered and reported many naturally occurring toxins that have been used in medications, hunting, and wars. In China, Emperor Shen Nung (2700 B.C.) documented having experimented with toxicants and medicinal plants. ${ }^{1}$ Eight Egyptian papyri dating from 1900-1200 B.C. reported the early use of poisons. ${ }^{1}$ The Ebers papyrus, dated 1500 B.C., contains the methodology for collections, preparations, and administrations of more than $800 \mathrm{drugs}$ and poisonous recipes, ${ }^{1}$ including opium to alleviate pain. Hindu medicine in India from 800 B.C. to 1000 A. D. references poisons and antidotes. The Greek army physician, Dioscorides (A.D. 50100), was assigned to classify toxicants. ${ }^{1}$ The Romans (A.D. $50-400$ ) made use of poisons for executions and assassinations. ${ }^{1}$ Avicenna (A.D. 980-1036), a master of many disciplines, was considered to be an Islamic authority on poisons and their antidotes. In A.D. 1198, Rabbi Moses ben Maimon (died in December 13, 1204, Fustat, Egypt) wrote a book entitled "Poisons and Their Antidotes" which was a first-aid guide to the treatment of poisoning. Swiss physician Paracelsus (1493-1541), the father of modern toxicology, stated that all compounds are toxic, provided the dose is high enough. The fall of the Roman Empire has historically been attributed to lead poisoning, ${ }^{2}$ and there is lead found in narcotics today that can cause poisoning. ${ }^{3}$ Deaths from toxicants are important aspects of medicine, particularly forensic medicine.

In death, cells die and enzymes digest the cells from inside out in a process called "autolysis." Gastrointestinal tract bacteria destroy the soft tissue-producing liquids, and volatile molecules such as hydrogen sulfide, carbon dioxide, methane, ammonia, sulfur dioxide, and hydrogen attract insects, orders Diptera (flies) and Coleoptera (beetles). ${ }^{4}$ The first recorded incident in which insects were used in a criminal investigation was in $13^{\text {th }}$ century China, as described in Sung Tzu's book entitled "The Washing Away of Wrongs" ${ }^{4,5}$ When a farmer was found murdered in a field with a sharp weapon, all the suspects were told to place their sickles on the ground. ${ }^{4}$ Only one sickle attracted blowflies to the trace amount of blood hidden to the naked eye, which resulted in the confession by the murderer. ${ }^{6}$ The use of entomology as a tool in forensic investigations was documented in $18^{\text {th }}$ century in France, where entomological data was admitted as proof for the acquittal of the occupants of a residence where skeletonized remains of a child were found. Mégnin (1828-1905) established the science of forensic entomology by evaluation of the insect succession on corpses. $^{7}$

Entomo-toxicology is a valuable field that intends to determine the time of death, known as postmortem interval (PMI). PMI is the time between the death and discovery of a corpse. PMI can be determined by using insect colonization, calculating the age of immature insect stages feeding on a corpse, and analyzing the necrophagous species present on a cadaver. ${ }^{5,8-11}$ Furthermore, entomo-toxicology has seen significant advancements regarding the detection and identification of toxicants in bodies that have been considerably decomposed or burned where fluids and tissue may be at a premium. ${ }^{5,8,9}$ However, different environmental factors can affect not only the time for an appearance on a cadaver but also the insect composition. It has been demonstrated that some household products, including insecticide, can increase development time, decrease the size of adult flies, and even influence insect survival rates. ${ }^{12}$ It has also been noted that insecticide can alter insect fauna and entomological succession. ${ }^{13}$ One study noted that Coleopteran insects (adults and larvae) were predominate and double the proportion of dipterous insects (adults and maggots) for zinc phos- 
phide-intoxicated dead groups in the winter season compared to that of control. ${ }^{14}$ Studies by Tellez et al, ${ }^{15}$ reported that the insecticide did slow insect feeding on the ortho-treated chicken, and thus, its decomposition was significantly delayed. However, the untreated chicken decomposed after one week of the experiment and significant insect attraction activity was observed. This indicates the necessity of considering the effects of environmental toxicants on a cadaver when investigating and determining an estimated PMI, as the normal insect succession can be skewed or delayed by the use of chemicals, such as the pesticides.

All in all, environmental toxicants, including but not limited to pesticides and heavy metals, can alter both the living organisms and the decomposition rate of dead organisms. This must be considered in the practice of forensic entomo-toxicology.

\section{CONFLICTS OF INTEREST}

The authors declare that they have no conflicts of interest.

\section{REFERENCES}

1. Hughes WW. Essentials of Environmental Toxicology: The Effects of Environmentally Hazardous Substances on Human Health. Boca Raton, Florida, USA: CRC Press. 1996.

2. Gilfillan SC. Lead poisoning and the fall of Rome. J Occup Med. 1965; 7(2): 53-60.

3. Soltani NK, Faryadi M, Akhgari M. Determination of lead in opium by flame atomic absorption spectroscopy. Scientific J Forensic Med. 2004; 9(32): 176-179.

4. Joseph I, Mathew DG, Sathyan P, Vargheese G. The use of insects in forensic investigations: An overview on the scope of forensic entomology. J Forensic Dent Sci. 2011; 3(2): 89-91. doi: $10.4103 / 0975-1475.92154$

5. Wallace DR. Evolution of Forensic Entomotoxicology. Toxicol Forensic Med Open J. 2017; SE(1): Se1-Se4. doi: 10.17140/TFMOJSE-1-e001

6. Catts EP, Goff ML. Forensic entomology in criminal investigations. Annu Rev Entomol. 1992; 37: 253-272. doi: 10.1146/annurev. en.37.010192.001345

7. Amendt J, Krettek R, Zehner R. Forensic entomology. Naturwissenschaften. 2004; 91(2): 51-65. doi: 10.1007/s00114-003-0493-5

8. Gosselin M, Wille SM, Fernandez Mdel M, et al. Entomotoxicology, experimental set-up and interpretation for forensic toxicologists. Forensic Sci Int. 2011; 208(1-3): 1-9. doi: 10.1016/j. forsciint.2010.12.015.

9. Sharma M, Singh D. Historical approach of forensic entomology: A review. International Journal of Advanced Research in Science, Engineering and Technology. 2015; 2(9).

10. Amendt J, Richards CS, Campobasso CP, Zehner R, Hall MJ. Forensic entomology: Applications and limitations. Forensic Sci Med Pathol. 2011; 7(4): 379-392. doi: 10.1007/s12024-010-9209-2

11. Haskell NH, Hall RD, Cervenka VJ, Clark MA. On the body: Insect's life stage presence, their postmortem artifacts. In: Haglund WD, Sorg MH (Eds). Forensic Taphonomy: The Postmortem Fate of Human Remains. Boca Raton, Florida, USA: CRC Press. 1997.

12. Aubernon C, Devigne C, Hedouin V, Gosset D, Charbadize D. In Vitro effects of household products of calliphoridae larvae development: Implication for forensic entomology. J Forensic Sci. 2015; 60(1): 226-232. doi: 10.1111/1556-4029.12555

13. de Souza Sandoval RC, de Asencao Medeiros LR. Influence of insecticide on insect fauna of forensic importance in rat carcasses (Rattus norvegicuz) exposed in a suburban area near Atlantic rainforest fragments of southeastern Brazil. Revista Brasileira de Zoociências. 2013; 15 (1, 2, 3): 165-170.

14. Abd El-Bar MM, Sawaby RF, El-Hamouly H, Hamdy R. A preliminary identification of insect successive wave in Egypt on control and zinc phosphide-intoxicated animals in different season. Egyptian Journal of Forensic Sciences. 2016; 6(3): 223-234. doi: 10.1016/j.ejfs.2016.05.004

15. Tellez C, Thomas J, Bounds J, Sutherland L. Forensic entomology and the effect of ortho pesticide on decomposition in sunny conditions. https://pdfs.semanticscholar.org/8028/2074a10f7bfc 651667d7783d9a5f0e22afa1.pdf. 